\title{
MAIN THEORETICAL APPROACHES TO THE STUDY OF THE PROBLEM OF SELF-EFFICIENCY OF A SOCIAL SERVICES SPECIALIST'S INDIVIDUALITY
}

\author{
Nataliya Onopriyenko-Kapustina ${ }^{I}$ \\ ${ }^{1}$ PhD student, Ivan Zyazyun Institute of Vocational and Adult Education of the National Academy of \\ Pedagogical Sciences of Ukraine, Kyiv (Ukraine)
}

ORCID ID: https://orcid.org/0000-0001-7338-893X

UDC: 159.99

\begin{abstract}
The article presents the results of theoretical analysis of scientific approaches to the self-efficacy problem study of the individual in general and the social services specialist, in particular. The research stated the ambiguity of the interpretation of the concept of "self-efficacy" and, at the same time, the role of self-efficacy in successful professional activity. We identified the main approaches to the study of the self-efficacy problem study of the individual and related concepts, which are: socio-cognitive psychoanalytic behavioural; personal and activity; humanistic; subjective; effective; competence; resource, acmeological approach, etc.

We proposed the acmeological approach as a basis in the context of the study of the self-efficacy problems, and its development, within which self-efficacy should be considered as an essential factor in achieving professional social specialists" "acme". It is shown that self-efficacy should be studied because of the possibility of its development in specially organized psychological training and socio-psychological support of specialists' self-efficacy, their beliefs, belief in their ability to implement activities, evaluation of their effectiveness and expectations for self-realization, and professional activity.
\end{abstract}

Keywords: self-efficacy, theoretical approaches to the study of self-efficacy, acmeological approach, social services specialists.

Problem statement. The need for social protection of the general population in today's stressful conditions determines the special requirements for the activities of social services. After all, they are focused on ensuring the social welfare of the country, meeting a wide range of social needs of different categories of the population, regardless of their characteristics (status, age, gender, national or sexual minorities, political beliefs, etc.).

Accordingly, the requirements for social service specialists are growing, who must ensure the high quality of social services, their professional and personal development.

As a result, because of scientific research, the problem of finding psychological factors of the quality pro- fessional activity of specialists in the social protection area, which form a forceful basis for professional selfdevelopment and achievement of professional "acme" by specialists, becomes relevant.

One of such factors, in our opinion, is the specialists' self-efficacy, which is the basis of their selfconfidence, that they can effectively implement professional functions and provide social protection to all who need it.

However, due to the problems of self-efficacy, which are identified at the level of society (imperfect legislation, which despite the declaration of the state), directly at the level of social services activity and their training (emotionally stressful activities are often in extreme conditions and lack of proper psychological training in the pro-

Address for correspondence, e-mail: editpsychas@gmail.com

Copyright: (C) Nataliya Onopriyenko-Kapustina

This is an Open Access journal, all articles are distributed under the terms of the Creative Commons Attribution-NonCommercial-ShareAlike 4.0 International (CC BY-NC-SA 4.0) License (http://creativecommons.org/licenses/by-nc-sa/4.0/), allowing third parties to copy and redistribute the material in any medium or format and to remix, transform, and build upon the material, provided the original work is properly cited and states its license. 
DOI (Issue): https://doi.org/10.31108/1.2020.6.1

cess professional training) and personality levels of the specialist (high probability of emotional burnout and professional personality deformities) (Onoprienko-Kapustina, 2016), the self-efficacy development of social protection specialists is quite problematic.

Analysis of recent research and publications. It should be noted that the problem of self-efficacy is the subject of scientific attention of a large number of scientists who, in particular, proposed this concept, studied the content, components, manifestations of self-efficacy in various fields (Bandura, 1977, Bandura 2012; Mastenbroek, Jaarsma, Scherpbier, 2014; Schunk, Benedetto, 2015, etc).

Despite the extensive study of self-efficacy, today, there is no single understanding of this phenomenon, which is considered from different angles: given the effectiveness (Miles \& Maurer, 2012), self-realization (Kazanzhi, 2020; Kokun, 2016), motivation (Zanyuk, 1999; Wang, Wei, Harada \& Minamoto, 2010), the realization of the creative potential of the person and achievement of tops in professional activity (professional "acme") (Derkach \& Zazykin, 2003), features of formation of the person of experts in social work (Balakhtar, 2018), etc.

That is why it seems appropriate to single out and systematize scientific approaches to the problem of selfefficacy of the individual in general and social services in particular as a theoretical basis for studying this phenomenon, which determined the purpose of this article.

The article aims at analysing the main theoretical approaches to the study of the problem of self-efficiency of a social services specialist's individuality

\section{Presentation of the main material and research}

results. The analysis of the scientists' publications showed that there are many works in which self-efficacy was the subject of study (A. Bandura, O. Bondarchuk, A. Boyarintseva, V. Lukyanenko, T. Urdan, M. Scherer, etc.).

However, there is no single interpretation of the concept of "self-efficacy", and the process of its development is a complex and lengthy process of forming an assessment of personal effectiveness in professional activities, their beliefs, professional competence, and patterns of behaviour. The etymology of the concept of "self-efficacy" combines the two words "self-" and "-efficiency", which can be understood as a self-effective person - is one who can use their resources to perform specific actions as effec- tively as possible.

The term "self-efficacy of personality" is mostly interpreted as perceived self-efficacy. This is an assessment of a person's own ability to take any action in specific conditions. In this case, the perceived self-efficacy is determined contextually, concerning the particular task set before the person (used for psychological assessment). Besides, researchers do not develop generalized psychological techniques, but self-efficacy scales aimed at measuring selfesteem in certain areas of life (e.g. methods of human perception of their ability to demonstrate social skills in communicating with the opposite sex; manage their own positive and negative emotions and others. (Carey K., Carey M., 1993, pp. 219-224.) It is also worth noting another feature of the interpretation of self-efficacy used to denote a person's judgments about the actions he may take, regardless of the importance it attaches to them. For example, a person can appreciate their effectiveness in the implementation of professional responsibilities, without feeling much satisfaction, because they do not see prospects for their growth (Caprara, Servon, 2003).

A. Bandura is the founder of the concept of selfefficacy, the author of the socio-cognitive theory of personality considers self-efficacy as following: a "conscious ability of a person to withstand complex situations and influence the effectiveness of the individual as a whole" (Bandura, 1977, pp. 191-205); situation-specific construct (Bandura, 1993, pp. 117-148); a person's confidence in professional growth based on abilities (Bandura, 1997)

The researcher singled out the characteristics of self-efficacy that affect the behaviour of the individual level, strength and generalization (breadth). In particular, the self-efficacy level indicates a person's perception of the ability to perform different levels of complexity of a particular activity. The power of self-efficacy determines the degree of a person's confidence in his personal ability to carry out certain activities and influences the formation of his faith in his capabilities and abilities in case of failure. The generality of self-efficacy indicates the transfer of belief in their effectiveness, formed in one area of activity, to other areas.

After all, "human behaviour is motivated and regulated by a sense of self-adequacy to internal standards." 
Besides, the scientist notes that both adults and children have a sense of self-efficacy, which allows them to be more persistent, less anxious and rarely fall into depression (Bandura, 2000, pp. 34-36). A. Bandura focuses on different cognitive abilities, which are likely to determine the development of self-efficacy. In this case, it is its cognitive component that determines the cognitive style, ie the most characteristic behaviour in all spheres of life of the specialist (family relations, professional activities, interpersonal relationships, etc.).

Thus, a person may strive to achieve high results, a higher level of professional activity for the sake of reward and recognition (Dweck \& Legget, 1988, pp. 256-273). The relationship between activity focus and efficiency can have negative and positive results (Kohli, Shervani, \& Challaglla, 1998, pp. 263-274; Bell \& Kozlowski, 2002, pp. 497505). R. Stenberg argues that cognitive style involves selfmanagement of thought, which allows control and selfcontrol of thought processes. The latter directly or indirectly affect the quality of self-efficacy of the individual, ensuring its increase or decrease (Vintonov, 2010, pp. 64-69).

The development of self-efficacy of the individual requires cognitive skills to form their behaviour, the implementation of verbal self-suggestion, plastic entry into a state of physical or emotional uplift, which will contribute to success in business (Myers, 2000). Thus, motivational and cognitive factors are of particular importance in understanding individual behaviour in the context of social situations (Rotter, 1954).

Within the psychoanalytic approach, self-efficacy is described as a personal property that contains not only a quantitative aspect but also a qualitative one (how, with what effectiveness), because there is a motive of efficiency that motivates the individual to overcome feelings of inadequacy. The term "efficiency" (Latin efficientia) is understood as "achieving certain results with the minimum possible costs or obtaining the maximum possible volume of products from a given number of resources" (ShaposhnykDominska, 2015).

Within the humanistic approach, scientists consider self-efficacy as the following: in the context of selfactualization (Maslow, 1999), the ability to "be better" (K. Rogers, 1994), satisfying meta-needs and meta motivation through spiritual and practical growth, enriching internal potential to transform it into external, self-effective behaviour, self-actualization.

Kondakov described the self-efficacy as a person's confidence in their ability to maintain their motivation, mobilize cognitive resources and perform actions that are necessary to control certain events (Kondakov, 2000).

Proponents of the behavioural approach believe that self-efficacy depends on external factors (favourable or unfavourable environmental conditions), the impact of which will lead to different results. Thus, the achievement of high self-efficacy contributes to a favourable environment, and unfavourable - requires more effort from a person to change adverse environmental conditions and achieve success. Relatively low self-efficacy, an unfavourable environment will lead to helplessness, apathy, a tendency to accept this condition (Frager \& Faydyman, 2006, pp. 569-570).

The founders of the action approach (V. Romanets, V. Tatenko, etc.) consider self-efficacy in connection with the analysis of the act, due to the following: the maximum possible in the level of development of one's psyche and oneself as its subject. That is why each action is not limited to its specific content, but its effect of the aftereffect "is included in the permanent process of human selfenrichment by the results of their action" (Kirichuk, Romanets, 2002, pp. 169-173). In this case, each action in the life of the individual should be analysed not only in terms of the problem of cognition but also depending on its activity, self-efficacy, is in the context of mental self-development the main conditions for solving them (Wolf, 2010).

Action activity allows us to approach the functional study of the subject in terms of his ability to organize the internal resources of man, the external conditions at every moment of the act. The act testifies to a mental and spiritual act, because the soul is able to reveal itself in a person's personal attitude to the world, others and himself. The personality reveals the subjective goal during its own development in the ability to act creatively, to realize the maximum personal potential, developing the psyche to the possible limits of perfection. The individual seeks to maintain this level of development as long as possible, ensuring the formation of personal structures and the development of individuality in general (Tatenko, 2006, pp. 3-13; Shulga, 2012, pp. 241-250). 
In the context of the subjective approach, selfefficacy is considered as a special ability of a person to be an active subject of his own life (Brushlinsky, 2003, pp. 1517), etc.). Scientists understand self-determination as a feeling of freedom from the forces of the external environment and the internal forces of the individual, which "helps to predict and explain the development of behaviour from simple reactivity to integrated values; from heteronomy to autonomy concerning those behaviours that are initially devoid of intrinsic motivation" (Desi \& Ryan, 1986, p. 188).

The development of intrinsic motivation determines the activity of the individual and the satisfaction of basic needs (according to theory): the need to be autonomous, i.e. able to self-initiate and self-regulate activities, in contrast to situations of coercion and seduction; the need to be competent, able to achieve the desired results; the need to feel meaningful, that is, to be "involved" in the process (Ryan \& Connell, 1989, pp. 749-761). Internal resources, forming the personal potential of the individual (Leontiev et al., 2007, pp. 8-31), help the individual to overcome adverse conditions of its development, self-awareness and create an active internal position of the individual, which allows for the development of autonomy in AbulkhanovSlavsk behaviour, 1973; Desi, 1986).

Considering the problems of self-efficacy and its development, it is worth mentioning the words of the German thinker F. Hegel, who argued that "circumstances and motives prevail over men only to the extent that they allow themselves to do so" (Hegel, 1971, p. 200). This thesis suggests that only man determines whether to allow circumstances and motives to dominate him or not.

Besides, self-efficacy is facilitated by belief in one's abilities and abilities on the way to self-realization in professional activities, belief in one's own ability to perform a specific activity, awareness of personal competence, confidence in abilities and faith in the ability to successfully perform certain tasks; that is, to achieve a high level of self-efficacy by activating self-esteem (Gordeeva, 2006).

Within the competence approach, self-efficacy is interpreted as a property of the individual, which characterizes his ability to manage their development and activities to effectively achieve certain tasks (Newstrom, 2000; Tolochek, 2004, etc.). Self-efficacy, according to $\mathrm{M}$.
Eneeva, combines the following basic components: planning, self-management, goal-setting and self-control, which are especially relevant for the training of future professionals (Eneeva, 1999).

A meaningful determinant of reception, information processing, decision-making, and life satisfaction experiences, as noted by scientists (Golovina \& Skotnikova, 2010, pp. 69-82), is self-confidence, a stable personal characteristic. Confidence is a multifunctional systemic mental education, the functions of which are: predicting the correctness of decisions (cognitive), reflection on the received information (metacognitive), experiences and states that affect the outcome of decisions (regulatory) and assessment of correctness (cognitive-regulatory)) (Skotnikova, 2005, pp. 84-99).

The article considers the self-efficacy within the personality-activity approach as the following:

- a substructure of consciousness, the cognitive mechanism is associated with self-assessment of personal abilities in the implementation of specific tasks or success in relationships with others, the degree of confidence in the successful completion of peculiar tasks, particular activities (Boyarintseva, 1995; Krichevsky, 2007);

- $\quad$ self-assessment - an emotional and evaluative system that reflects the degree of positive (negative) in the individual's attitude to himself (Pantileev, 1993);

- reflection, etc. Self-efficacy indicates the result of activity, and "reflection is a process included in selfregulation that permeates all components of consciousness" (Makarenko, 2015, p. 181).

Man is a subject of his development, creativity, and his development depends not only on the influence of external factors but also on his activity aimed at developing creative potential and achieving self-efficacy (Rubinstein, 1986, pp. 101-107).

The conceptual approach of O. Bondarchuk (2015) attracts attention in the context of the researched problem. The author developed a model of psychological training of heads of educational organizations to work in conditions of change, projects their activities aimed at the ability to be effective in the modern synergetic paradigm of the educational process. 
Self-efficacy, as the researcher notes, is "the teacher's inner conviction that he has the necessary potential and level of professional competence to realize the role expectations of all subjects of the educational process in situations of pedagogical and business communication." (Bondarchuk, 2018, c. 5-24).

Within the framework of the resource approach, V. Balakhtar investigates the formation personality of a social work specialist, focusing on value-motivational, cognitiveaffective and conative-reflexive spheres and professionalpersonal neoplasms at different stages of professionalization, which requires socio-psychological support of the specialist and creating "optimal conditions for effective adaptation to learning professional activity, the interaction between all parts of the educational process / professional activity that ensures the formation of professional personal neoplasms at different stages of personality formation of social work specialists (self-determination as a social work specialist; design (life construction) of a professional path; self-regulation, self-affirmation, self-improvement and selfrealization in professional activity; reflections on professional experience and self-creation of the meaning of further life). The scientist claims that the successful organization of social and psychological support will contribute to the personal growth, formation and achievement of selfefficacy of a specialist in professional activities.

Thus, the scientific publications and literature analysis shows the ambiguity of the interpretation of the concept of "self-efficacy", but at the same time, in the context of studying the problem of self-efficacy is an important acmeological approach, in which self-efficacy is considered through a person's belief in his ability to and development to be a productive person, to reach the top of "acme" (Derkach \& Zazykin, 2003, etc.).

As for the self-efficacy of social services professionals, we consider it as an essential factor in achieving future professional "acme" based on self-confidence (inner convictions), faith and ability to succeed in professional activities in the field of social services, the ability to provide quality social services to various categories, including vulnerable.

Conclusions. According to the results of the theoretical analysis, the ambiguity of the interpretation of the concept of "self-efficacy" was revealed. The main approaches to the study of the problem of self-efficacy of the individual are identified: socio-cognitive (self-efficacy as a conscious ability to withstand complex situations and influence the effectiveness of the individual's functioning and functioning in general); psychoanalytic (self-efficacy as a personal trait that motivates the individual to overcome feelings of inadequacy (inferiority); behavioural (selfefficacy depends on the degree of favourable environmental conditions that allow individuals to succeed); to achieve the maximum possible at the level of development of one's psyche and oneself as its subject); subjective (self-efficacy as one's activity, one's ability to independently choose the direction of self-determination, self-development, selfrealization, etc.); competence (self-efficacy as personality competence), which characterizes its ability to manage their development and activities for the effective achievement of specific tasks); personal activity (self-efficacy as a substructure of consciousness associated with self-esteem, selfreflection, reflection, the degree of confidence in the specific tasks successful solution, in performance of definite activities; resource approach (self-efficacy as an "internal" psychological determinant of personality development, realization of its potential), acmeological approach (selfefficacy as a person's belief in the ability to find their place in society, manage their behaviour and development to be productive personality, reach acme heights ) etc.

An acmeological approach is proposed as a basic one, within which self-efficacy is considered as an essential factor in the achievement of professional "acme" by future social specialists. We study self-efficacy because of the possibility of its development in specially organized psychological training, providing socio-psychological support for the development of self-efficacy of professionals, their beliefs, and belief in their ability to implement activities, self-assessment and expectations for self-realization in future professional activities.

\section{References:}

Abulkhanova-Slavskaya, K.A. (1973). O subiyekte psikhicheskoy deyatelnosti [About the subject of mental activity]. M.: Nauka.

Balakhtar, V. V. (2018). Samoefektyvnist yak indykator stanovlennya osobystosti fakhivtsya z sotsialnoyi roboty yak profesionala [Selfefficacy as an indicator of the formation of the personality of a 
social worker as a professional]. Molodyy uchenyi, №9(61), 165170.

Balakhtar V. V. (2019). Psykholohiya stanovlennya osobystosti fakhivtsya iz sotsialnoyi roboty [Psychology of the formation of the Social Work specialist's personality]. (Doctoral Dissertation). Institute of Psychology by G. S. Kostiuk, National Academy of Educational Sciences of Ukraine, Kyiv

Bondarchuk, O. I. (2015). Rol samoefektyvnosti menedzheriv orhanizatsiy u rozvytku orhanizatsiynoyi kultury osvitnikh orhanizatsiy [The role of self-efficacy of managers of organizations in the development of organizational culture of educational organizations]. Psykholohichni determinanty rozvytku orhanizatsiynoyi kultury (monohrafiya), 138-166.

Bondarchuk, O. I. (2018). Sotsialna samoefektyvnist pedahohichnykh pratsivnykiv yak chynnyk psykholohichnoyi bezpeky osvitnioho seredovyshcha [Social self-efficacy of teachers as a factor in the psychological security of the educational environment.]. Zbirnyk naukovykh statey Kyyivskoho mizhnarodnoho universytetu y Instytutu sotsialnoyi ta politychnoyi psykholohiyi NAPN Ukrayiny. Seriya: "Psykholohichni nauky: problemy i zdobutky», 2(12), 524

Boyarintseva, A. V. (1995). Motivatsionno-kognitivnyye kharakteristiki lichnosti molodogo predprinimatelya. (Dissertatsiya). Moskva.

Brushlinskiy, A. V. (2003). Psikhologiya subyekta [Psychology of the subject]. Psikhologicheskiy zhurnal, 24(2), 15-17.

Gegel, G. V. (1971). Filosofskaya propedevtika [Philosophical propaedeutics]. Raboty raznykh let: V 2 t., 2, 5-209. M.: Mysl.

Gordeyeva, T. O. (2006). Psikhologiya motivatsii dostizheniya [The psychology of achievement motivation]. Moskva : Smysl, izdatelskiy dom «Akademiya».

Vintoniv, M. I. (2010). Kohnityvni styli abo v yakyy sposib my myslymo [Cognitive Styles or the Way We Think], Praktychna psykholohiya ta sotsialna robota, 9, 64-68.

Vovk, O. M. (2010). Samoefektyvnist: sutnist, struktura ta osoblyvosti rozvytku v studentskomu vitsi [Self-efficacy: essence, structure and features of development at student age]. Visnyk psykholohiyi $i$ sotsialnoyi pedahohiky, 3. Retrieved from: www.psyh.kiev.ua

Golovina, Ye. V. \& Skotnikova, I. G. (2010). Kognitivno-stilevaya struktura fenomena uverennosti [The cognitive-style structure of the phenomenon of confidence]. Psikhologicheskiy zhurnal, 31 (4), 69-82

Derkach, A. A. \& Zazykin, V. G. (2003). Akmeologiya [Acmeology]. Sankt-Peterburg : Piter. [in Russian]

Eneyeva, M. YU. (1999). Psikhologicheskiye komponenty subyektnosti studenta [Psychological components of a student's subjectivity]. (Dissertatsiya). Moskva : [b. v.]

Zanyuk, S. S. (1999). Psykholohiya motyvatsiyi ta emotsiyi [Psychology of motivation and emotions.]. Lutsk : RVV VDU im. Lesi Ukrayinky.
Kazanzhy, M. Y. (2020). Samozdiysnennya osobystosti: sutnist i spetsyfichni kharakterystyky [Self-realization of personality: essence and specific characteristics]. Naukovyy visnyk Khersonskoho derzhavnoho universytetu, 1, 27-33.

Kaprara, Dzh. \& Servon, D. (2003). Psikhologiya lichnosti [Psychology of Personality]. Sankt-Peterburg: Piter.

Kyrychuk, O.V., \& Romenets, V.A. (Red.) (2002). Osnovy psykholohiyi [Fundamentals of psychology]. Kyiv.

Kokun, O. M. (2016). Chynnyky profesiynoho samozdiysnennya osobystosti (statevi osoblyvosti) [Factors of professional selfrealization of the individual (sexual characteristics)]. Aktualni problemy psykholohiyi, V, 16. Retrieved from: http:// www.appsychology.org.ua/data/jrn/v5/i16/10.pdf.

Kondakov, I. M. (2000). Psikhologiya-2000: Illyustrirovannyy spravochnik [Psychology 2000: Illustrated reference book]. Stolichn. gumanitarn. in-t. Moskva. Retrieved from: http:// www.encyclopedia.ru/cat/online/detail/38841

Krychevskyy, R. L. (2007). Psykholohiya liderstva [Psychology of leadership]. M. : Statut.

Mayyers, D. Dzh. (2000). Sotsialnaya psikhologiya: intensiv. kurs . (3-ye mezhdunar. izd.) [Social psychology: intensive. course. (3rd international ed.)]. Sankt-Peterburg : Praym-Yevroznak: Neva; Moskva : OLMa-Press.

Makarenko, I. YE. (2015). Profesiyno-osobystisna samootsinka pedahoha yak odyn iz vazhlyvykh chynnykiv formuvannya yoho samoefektyvnosti [Professional and personal self-esteem of a teacher as one of the important factors in the formation of his self-efficacy]. Naukovyy visnyk Mykolayivskoho natsionalnoho universytetu imeni V. O. Sukhomlynskoho. Pedahohichni nauky, 3, 180-185. Retrieved from: http://nbuv.gov.ua/UJRN/Nvmdup 2015335 .

Maslou, A. (1999). Novyye rubezhi chelovecheskoy prirody [New frontiers of human nature]. Moskva : Smysl.

Niyustrom, Dzh. V. (2000). Organizatsionnoye povedeniye Povedeniye cheloveka na rabochem meste. Seriya «Teoriya $i$ praktika menedzhmenta» [Organizational behavior. Human behavior in the workplace. Series "Theory and Practice of Management"]. (per. s angl. pod red. YU.N.Kapturevskogo). SPb. : Piter.

Onopriyenko-Kapustina, N. V. (2016). Problemy rozvytku samoefektyvnosti maybutnikh fakhivtsiv sotsialnykh sluzhb [Problems of development of self-efficacy of future specialists of social services]. Psykholoho-pedahohichnyy suprovid fakhovoyi pidhotovky ta pidvyshchennya kvalifikatsiyi osobystosti $v$ umovakh transformatsiyi osvity: Tezy Vseukrayinskoyi naukovo-praktychnoyi konferentsiyi $K$. : DVNZ «Universytet menedzhmentu osvity», C. 75 77. Режим доступу: http://umo.edu.ua/konferenciji-ta-seminari.

Pantileyev, S. R. (1993). Metodika issledovaniya samootnosheniya [Selfattitude research method]. Moskva : Smysl

Rodzhers, K. R. (1994). Vzglyad na psikhoterapiyu. Stanovleniye chelove$k a$ [A look at psychotherapy. Becoming a man]. M. M. Iseninoy 
DOI (Issue): https://doi.org/10.31108/1.2020.6.1

(Perev.). Moskva : Progress : Univers

Skotnikova, I. G. (2005). Eksperimentalnoye issledovaniye uverennosti v reshenii sensornykh zadach [An experimental study of confidence in sensory task solving]. Psikhologicheskiy zhurnal, 26 (3), 84-99.

Tatenko, V. O. (2006). Subiyektno-vchynkova paradyhma v suchasniy psykholohiyi [Subject-action paradigm in modern psychology]. Sotsialina psykholohiya, 1(15), 3-13.

Tolochek, V. A. (2004). Organizatsionnaya psikhologiya: upravleniye personalom [Organizational psychology: personnel management]. M. : Mir bezopasnosti

Shaposhnyk-Dominska, D. O. (2015). Psykholohichni osoblyvosti rozvytku samoefektyvnosti osobystosti [Psychological features of the development of self-efficacy of the individual]. (Dysertatsiya). Kyiv: Instytut sotsialnoyi ta politychnoyi psykholohiyi NAPN Ukrayiny.

Freydzher, R. \& Feydimen, Dzh. (2006). Lichnost. Teorii, uprazhneniya, eksperimenty [Personality. Theories, exercises, experiments] (per. s angl. Ye. Budagovoy, M. Vasil'yevoy, V. Kucheryavkina et al). SPb. : Praym-YEVROZNAK, (Bolshaya universitetskaya biblioteka)

Shulha, V. D. (2012). Vchynok yak ontolohichnyy mekhanizm rozvytku sutnisnykh syl lyudyny [Action as an ontological mechanism of development of essential human forces]. Naukovi studiyi $i z$ sotsialnoyi ta politychnoyi psykholohiyi, 30, 241-250.

Bandura, A. (1977). Self-efficacy: Toward to unifuing theory of behavioral change. Psychological review, 84 (2), 191-205.

Bandura, A. (2012). On the functional properties of perceived self-efficacy revisited. Journal of Management, 38, 9-44. Retrieved from: https://doi.org/10.1177/0149206311410606

Bell, B. S. \& Kozlowski, S. W. (2002). Goal Orientation and Ability: Interactive Effects on Self-Efficacy. Performance, and Knowledge. J. Appl. Psychol, 87, 497-505.

Carey, K. B., \& Carey, M. P. (1993). Changes in self-efficacy resulting from unaided attempts to quit smoking. Psychology of Addictive Behaviors, 7(4), 219-224. https://doi.org/10.1037/0893164X.7.4.219

Deci, E. \& Ryan, R. (1986). The dynamics of self-determination in personality and development. Self-related cognitions in anxiety and motivation, 171-194.

Dweck, C. S. \& Legget, E. L. (1988). A social-cognitive approach to motivation and personality. Psychol. Rev., 95, 256-273.

Kohli, A. K., Shervani, T. A. \& Challaglla, G. N. (1998). Learning and Performance Orientation of Salespeople: The Role of Supervisors. J.Mark. Res., 35(2), 263-274.

Mastenbroek, N.J.J.M, Jaarsma, A.D.C, Scherpbier, A.J.J.A. (2014). The role of personal resources in explaining well-being and performance: A study among young veterinary professionals. European Journal of Work and Organizational Psychology, 23(2), 190-202
Volume 6 Issue 12020

Miles, E. W. \& Maurer, T. J. (2012). Advancing validity of self-efficacy in negotiation through focusing at the domain level. Journal of Occupational and Organizational Psychology, 85 (1), 23-41.

Ryan, R. M. \& Connell, J.P (1989). Perceived locus of causality and internalization: Examining reasons for acting in two domains. Journal of Personality and Social Psychology, 57, 749-761.

Rotter, J. B. (1954). Social learning and clinical psychology. Englewood Cliffs. NJ. : Prentice-Hall. doi.org/10.1037/10788-000

Schunk, D. H, Di Benedetto, M. K. (2015). Self-efficacy: education aspects. In: Wright JD, editor. International Encyclopaedia of the Social \& Behavioral Sciences. 2nd edition, 515-521.

Wang, J., Wei, C., Harada, K. \& Minamoto, K. (2010). Applying the social cognitive perspective to volunteer intention in China: the mediating roles of self-efficacy and motivation. Health Promotion International Retrieved from: https://academic.oup.com/ heapro

\section{Онопрієнко-Капустіна Наталія Василівна}

Здобувач наукового ступеню кандидата наук (PhD), Iнститут професійної освіти $і$ освіти дорослих імені Івана Зязюна Національної академї педагогічних наук України, м. Київ (Украӥна)

\section{ОСНОВНІ ТЕОРЕТИЧНІ ПІДХОДИ ДО ДОСЛІДЖЕННЯ ПРОБЛЕМИ САМОЕФЕКТИВНОСТІ ОСОБИСТОСТІ ФАХІВЦЯ СОЩАЛЬНИХ СЛУЖБ}

\section{АНОТАЦІЯ}

У статті подано результати теоретичного аналізу наукових підходів до дослідження проблеми самоефективності особистості загалом і фахівця соціальних служб зокрема. Констатовано неоднозначність трактування поняття «самоефективність» i, водночас, роль самоефективності в успішній професійній діяльності. Виокремлено основні підходи до дослідження проблеми самоефективності особистості та близьких до неї понять: соціально-когнітивної теорії (як усвідомлену здатність протистояти складним ситуаціям та впливати на ефективність діяльності і функціонування особистості в цілому); психоаналітичного підходу (як особистісну властивість, що містить не лише кількісний аспект, а й якісний; прагнення до самоактуалізації, впевненості людини у своїй здатності підтримувати власну мотивацію, мобілізувати когнітивні ресурси та здійснювати дії, які необхідні для контролю над певними подіями; біхевіористичний (залежно від сприятливих (несприятливих умов довкілля), що дозволяють досяг- 
нути успіху); вчинкового підходу (у зв'язку з аналізом вчинку, що дозволяє виявити і реалізувати свій потенціал); суб'єктного підходу (як власну активність людини, iii здатність до самостійного вибору напряму самовизначення, сморозивтку, самореалізації та ін.); компетентнісного підходу (як властивість особистості, що характеризує їі здатність управляти власним розвитком і діяльністю задля ефективного досягнення визначених завдань; здатність особистості до самостійного вибору напрямку самореалізації, формування позитивних аспектів психології особистості); акмеологічний підхід (як переконання людини щодо здатності знаходити своє місце у соціумі, самостійно управляти власною поведінкою та розвитком з метою бути продуктивною особистістю, досягнути вершин «акме»); особистіснодіяльнісного (як підструктуру свідомості, когнітивний механізм пов'язаний з самооцінкою, ступенем впевненості в успішному розв'язанні певних завдань, виконання конкретної діяльності, самоставленням, рефлексією тощо) та ін. В якості базового у контексті дослідження проблем самоефективності та її розвитку запропоновано акмеологічний підхід, у межах якого самоефективність доцільно розглядати як важливий чинник досягнення соціальними фахівцями професійного «акме». Показано, що самоефективність при цьому доцільно вивчати 3 огляду на можливість іiї розвитку в спеціально організованому психологічному навчанні та соціально-психологічному супроводі розвитку самоефективності фахівців, їхньої переконаності, віри у власні можливості реалізовувати діяльність, оцінку власної ефективності та очікування щодо неї на шляху до самореалізації у професійній діяльності.

Ключові слова: самоефективність, теоретичні підходи до дослідження самоефективності; акмеологічний підхід, фахівці соціальних служб.
Оноприенко-Капустина Наталья Васильевна

Соискатель научной степени кандидата наук (PhD), Институт профессионального образования и образования взросльх имени Ивана Зязюна Национальной академии педагогических наук Украинь, 2. Киев (Украина)

\section{ОСНОВНЫЕ ТЕОРЕТИЧЕСКИЕ ПОДХОДЫ К ИССЛЕДОВАНИЮ ПРОБЛЕМЫ САМОЭФФЕКТИВНОСТИ ЛИЧНОСТИ СПЕЦИАЛИСТА СОЦИАЛЬНЫХ СЛУЖБ}

\section{АННОТАЦИЯ}

В статье представлены результаты теоретического анализа научных подходов к исследованию проблемы самоэффективности личности в целом и специалиста социальных служб в частности. Констатирована неоднозначность трактовки понятия «самоэффективность» и одновременно роль самоэффективности в успешной профессиональной деятельности. Выделены основные подходы к исследованию проблемы самоэффективности личности и близких к ней понятиям: социально-когнитивной теории (как осознанную способность противостоять сложным ситуациям и влиять на эффективность деятельности и функционирования личности в целом); психоаналитического подхода (как личностное свойство, содержащее не только количественный аспект, но и качественный, стремление к самоактуализации, уверенность человека в своей способности поддерживать собственную мотивацию, мобилизовать когнитивные ресурсы и осуществлять действия, необходимы для контроля над определенными событиями; бихевиористического (в зависимости от благоприятных (неблагоприятных) условий окружающей среды, позволяющей достичь успеха), субъектного (как собственную активность человека, его способность к самостоятельному выбору направления самоопределения, саморазвития, самореализации и др.) компетентностного (как свойство личности, характеризующее ее способность управлять собственным развитием и деятельностью для эффективного достижения определенных задач, способность личности к самостоятельному выбору направления самореализации, формирования позитивных аспектов психологии личности); акмеологического (как убеждения человека, его способности находить свое место в социуме, самостоятельно управлять собственным поведением и развитием с целью быть продуктивной личностью, достичь вершин 
«акме»); личностно-деятельностного (как подструктуру сознания, когнитивный механизм связан с самооценкой, степенью уверенности в успешном решении определенных задач, выполнение конкретной деятельности, самоотношением, рефлексией и т.д.) и др. подходов. В качестве базового в контексте исследования проблем самоэффективности и ее развития предложено акмеологический подход, в рамках которого самоэффективность целесообразно рассматривать как важный фактор достижения социальными специалистами профессионального «акме». Показано, что самоэффективность при этом целесообразно изучать учитывая возможность ее развития в специально организованном психологическом обучении и социально-психологическом сопровождении развития самоэффективности специалистов, их убежденности, веры в собственные возможности реализовывать деятельность, оценку собственной эффективности и ожидания относительно нее на пути к самореализации в профессиональной деятельности.

Ключевые слюва: самоэффективность, теоретические подходы к исследованию самоэффективности, акмеологический подход, специалисты социальных служб. 